\title{
The Effect of Two Aspects-Quality Products and Consumers Psychology - Toward the Purchase Decisions of Samsung Mobile Phone
}

\author{
SiskaYulianda \\ Tati Handayani
}

1)UPN "Veteran" Jakarta; Email:tatihandayani01@gmail.com

\author{
Doi:10.5901/mjss.2015.v6n5s5p203
}

\begin{abstract}
This research is written to prove the effect of product quality and the consumer psychology as a moderating variable of Samsung gt-i8262 cores purchase decisions on residing within the RW10 Pondok cabe ilir Pamulang, with 100 samples. Sempel determination techniques use purposive sampling method. This study hypothesis there is positive and significant impact on product quality and consumer psychology on purchase decision- of-core mobile phone Samsung gt-18262.Data analysis method used is moderate. Regression analysis method was used to determine the effect of independent variables relationship: product quality and psychological consumer and the dependent variable, core mobile Samsung gt-l8262 purchasing decisions .
\end{abstract}

Keywords: Product Quality, Consumer Psychology, Purchasing Decisions.

\section{Introduction}

Today, we could find various smart phones, ranging from high to low price. Various brands of mobile phones are flourishing in market at varying prices. This makes manufacturers continually strive to compete and create the latest innovations. However then, other mobile phones brands are not less competitive than Samsung Galaxy mobile phone . They provide features and applications that are as good as brand Samsung Galaxy mobile phones.. Mobile phone manufacturers continue to provide the best features and applications, so that users can assess or be motivated to buy the mobile phone product. After seeing the promotion given by marketers, consumers will get information about the product. Consumers who have received the information, will likely inquire about such information from family and, closest friends which make it possible to convince them to decide to making mobile phone. Smart phone market share in 2013 second quarter was marked by the Samsung dominance that managed to record market share of $30.4 \%$ or $43.9 \%$ growth from year to year. The rapid demand for the Galaxy S4 smartphone in the world market became the biggest contributors on this achievement.

Isyanto, et al (2012) stated that quality of mobile products were favorably affected by performance, features, reliability, conformation, durability, ability to service, aesthetics, and quality. Also, in accordance with Sata \& Belete (2013), there are six independent variables including product quality : durability, brand names, product features, social influence and after-sales services. The main factor is price followed by the product's features and durability according to research written by Sata \& Belete (2013) .According to Fredereca \& Chaity (2010), the decision of product purchase is also influenced by psychological factors, namely the consumers of the four consumer psychological factors including motivation, perception, learning and attitudes.Mulyana \& Tandri (2012), stated that every consumer in product process is affected by the attitude in each mind. Positive perception will lead to positive behavior in consumer of the product according Mulyana \& Tandri (2012).

Uddin, et al (2014) stated that in deciding the product purchase, there are several factors that influence it. They are the various types of facilities and many other factors that are considered and expected as selection criteria by customer. In terms of choosing mobile phone brand, a large part is considered as factor by customers including product quality, pricing, charging and operation facilities, size and weight, friends and colleagues recommendations neighbors and advertising.

There are four variables that influence consumer behavior : cultural factors, social factors, personal factors, and psychological factors. Writer wanted to know more in depth about the consumer behavior, especially related to psychological factor in making purchasing decisions of Samsung brand mobile products. In fact,Samsung product has 
increased higher sales than its competitors like Aple with their iPhone, Samsung's product still has a large market share in Indonesia. Therefore, the authors are interested to know more in depth about consumer behavior on Samsung phone mobile products.

\section{Problems Formulation}

1. Does the product quality have positive influence on purchasing decisions?

2. Does the consumer's psychology have positive influence on purchasing decisions?

3. Does the consumer's psychology moderate the effect between the product quality and a purchase decision?

\section{Literature Review}

According to Kotler and Keller (2009, pp.143), quality is the total of products or services features and characteristics that depend on the ability to satisfy the needs expressed or implied'. Consumer behavior according to Kotler and Keller (2009, pp.166 ), is the study of how individuals, groups, and organizations select, buy, use and how goods, services, ideas, or experiences satisfy their needs and desires'.

Consumer behavior on making purchases is influenced by environmental factors, including culture, social class factors, personal factors and also the influence of psychological factors. Psychological factors consist of motivation, perception, learning and beliefs and attitudes

Buying Decision

Consumer decision making according to Sciffman \& Kanuk in Sumarwan (2011, pp.360) is decision making process of consumers purchase in a wide range of situations. If consumers want to buy durable goods, so consumers will do routine business to seek information. If consumers buy daily necessities, consumers will make purchases on a regular basis.

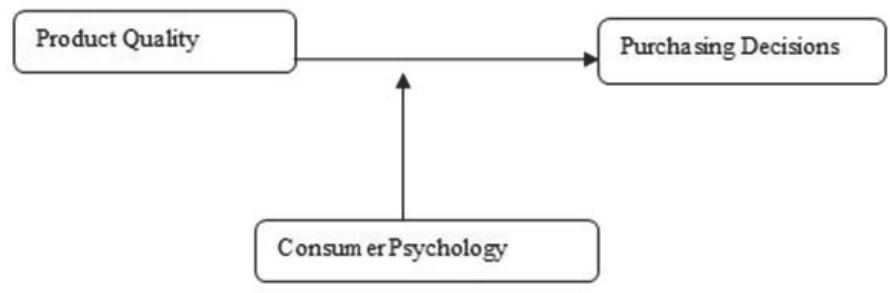

Figure 1. Framework

Research Hypothesis

$\mathrm{H1}$ : Product quality has positive influence on purchasing decisions.

H2: Psychological positive influence on consumer purchase decisions.

H3: Product quality and consumer psychology moderate effect to purchasing decisions.

\section{Research Method}

The variables in this study consisted of three

\subsection{Products Quality (X1)}

According to Jasfar (2009, pp.57), product quality can provide a clear picture of the product itself, like indicators of operational ease, shape, battery, service location, product design, and price suitability.

\subsection{Consumer Psychology (X2)}

According to Kotler and Keller (2009, pp.166), purchases making is influenced by environmental factors which is include 
culture, social class factors, personal factors and psychological factors. That indicators influence consumer motivation, learning consumers, consumer attitudes.

\subsection{Purchase Decision (Y)}

Seller needs to create buyer decision in overail structure to assist consumer I taking the purchase decision. The indicators are type of product, brand, place, purchase time, and payment method.

\subsection{Population and Sample}

The population in this study is citizens at the area of RW 10 Pondok Cabe llir Pamulang who use Samsung Galaxy mobile phones.. Samples were obtained from some consumers who already use Samsung Galaxy mobile phones. Sampling techniques that were used in non-probability sampling. The sample size is 100 respondents.

\subsection{Analysis Methods}

Data analysis method used is multiple linear regression analysis with moderating variables. Moderating variable is variable types that strengthen or weaken the direct relationship between the dependent and independent variables. (Ghozali, 2011, pp.223).

\section{Results}

\subsection{Validity Test}

Validity test results showed that the calculated value of each indicator is greater than the table value. This shows that the indicators of the product quality, the consumer's psychology, and purchasing decisions are declared valid as a factor of measuring research variables.

\subsection{Test Reliability}

The results of Cronbach's alpha value of the independent variable (product quality), moderating variables ( consumer psychology), and the dependent variable (purchase decisions) are greater than 0.60 . This suggests that the answer is reliable or consistent conclusions.

\subsection{Classical Assumption Test}

\subsubsection{Normality}

Sig value is obtained from output table. The value are $0.077,0.200$ and 0.199 in the Kolmogorov-Smirnov. These data are normally distributed because all of values of each variable $>0.05$

\subsubsection{Heteroscedasticity}

The test results of heteroscedasticity are as follows: 


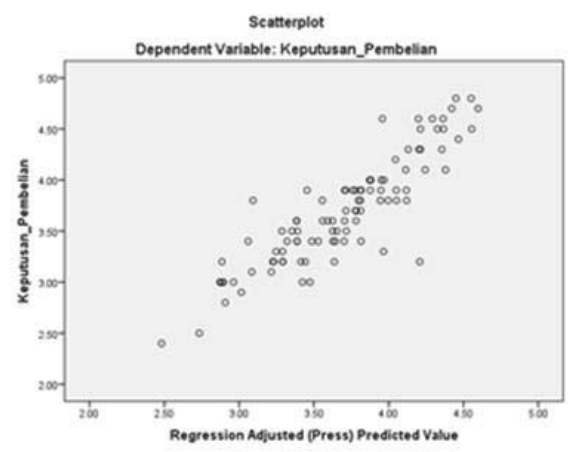

Figure 2. Heterocedasticity Test

Heterocedasticity test results on product quality and psychological variables of consumers does not happen because the picture shows heterocedasticity spread pattern.

\subsubsection{Multicollinearity}

VIF value calculation results also showed 1,913 where there are more than 10. It can be concluded that the regression model in this study does not contain multicollinearity.

\subsection{Multiple Regression Analysis with Variable Moderating}

Figure 3. ANOVA

\begin{tabular}{ccccccc}
\hline & Model & Sum of Squares & $\mathrm{df}$ & Mean Square & $\mathrm{F}$ & Sig. \\
\hline & Regression & 22.142 & 3 & 7.381 & 143.196 & $.000^{\mathrm{b}}$ \\
& Residual & 4.948 & 96 & .052 & & \\
& Total & 27.090 & 99 & & & \\
\hline
\end{tabular}

a. Dependent Variable: Purchasing Decisions

b. Predictors: (Constant), Moderate, Products Quality , Consumer Psychology

Figure 4. Test $\mathrm{t}$

\section{Coefficients $^{\mathrm{a}}$}

\begin{tabular}{|c|c|c|c|c|c|c|}
\hline \multirow{2}{*}{ Model } & \multicolumn{2}{|c|}{ Non standardized Coefficients } & \multirow{2}{*}{\multicolumn{2}{|c|}{$\begin{array}{c}\text { Standardized Coefficients } \\
\text { Beta }\end{array}$}} & \multirow{2}{*}{$\mathrm{t}$} & \multirow{2}{*}{ Sig. } \\
\hline & B & Std. Error & & & & \\
\hline \multirow{3}{*}{1} & (Constant) & .134 & .182 & & .736 & .464 \\
\hline & Products Quality & .821 & .065 & .779 & 12.580 & .000 \\
\hline & Consumer Psychology & .158 & .061 & .161 & 2.606 & .011 \\
\hline
\end{tabular}

Figure 5. Multiple Regression Analysis with Variable Moderating

\begin{tabular}{cccccc}
\hline Model & \multicolumn{2}{c}{ Non standardized Coefficients } & Standardized Coefficients & S & Sig. \\
& $\mathrm{B}$ & Std. Error & & & \\
\hline (Constant) & 2.391 & .932 & .170 & 2.566 & .012 \\
1Products Quality & .180 & .267 & 1.156 & .671 & .504 \\
Moderate & .177 & .072 & 2.468 & .015 \\
\hline
\end{tabular}

\subsection{Hypotheses Testing}

The $F$ test resulted in calculated $F$ value of 143.196 with a significance level of $0: 00$. Because significance probability is smaller than 0.05 , it can be said that both of product quality and, the consumer's psychology influence the purchase 
decision.

The test results show that partial hypothesis product quality variable has a value of t-test (12.580)> t-table value (1.9845), and a significant probability value of $0.000<0.05$. This means that the variable product quality partially influence purchasing decisions of Samsung mobile phone. Partial hypothesis test results of consumer psychology variable has t-test a value of $(-1.802)<t$-table value (1.9845), and a significant probability value of $0.75>0.05$. This means that partially consumer psychology variables did not influence purchasing decisions of Samsung mobile phone. Moderate variable test result, which is the interaction between product quality and consumer psychology change significantly. The t count value (2468)> t-table value (1.9845), and a significant probability value of $0.015>0.05$.. It can be concluded that psychological variables are consumer moderating variables. The impact of product quality, and consumer psychology variables to purchasing decisions simultaneously is $80.6 \%$, according to determination coefficient. Meanwhile, the remaining balance of $19.4 \%$ is influenced by other factors.

\section{Discussion}

Partial hypothesis testing results show that the variable quality of products has the value of $t$ count (12580)> t-table value (1.9845), and a significant probability value of $0.000<0.05$. This means that the product quality variable partially influence purchasing decisions on Samsung Galaxy Core GT - 18262. Based on the test results, there is similarity between this research and Isyanto, et al (2012) research which states that there is significant influence between the product quality variable buying decisions.

For consumer psychology variables, the test results using partial regression analysis showed that moderate value t count $(-1802)<t$-table value (1.9845), and a significant probability value of $0.75>0.05$. This means partially consumer psychology variables did not influence purchase decisions on Samsung Galaxy Core GT - 18262 in Pamulang. The results of this research has similarity with research written by Federeca and Chairy (2013) which stated that no significant influence of psychological variables on purchase decisions.

Furthermore, the test results of moderate variable which is the interaction between product quality and consumer psychology, change significantly. With the value of t count (2468)> t-table value (1.9845), and significant probability value of $0.015<0.05$. It can be concluded that psychological variables are consumer moderating variables.

\section{Conclusion}

Based data analysis an hypotheses test on products quality and consumer Psychology variables, the author concludes that partial product quality has significant influence on purchase decision, but psychological variables did not affect the consumer purchasing decision. Consumer Psychology variables moderate the relationship between the purchase decision factors. After product quality is tested simultaneously, two variables significantly influence the purchase decision.

\section{Suggestions}

The company is expected to increase sales by implementing strategies that can be seen from the indicators of psychological variables and consumer product quality. They could be more active in certain events and conduct interesting offers by providing a promotional price. Therefore, they will eventually attract consumers to buy them.

\section{References}

Assael Henry, (2002) Consumer Behavior and Marketing Action, Fifth Edition. Cincinnati Ohio: South-Western College Publishing. Blogs pot, history-samsung-and-android, Accessed on 28 November 2014 http://habibi7977.blogspot.com/2013/10/.

Engel J.F Miniard P.W., dan Blackwell R.D., (2006) Consumer behavior, 9th ed, USA: Harcourd

Fredereca, BG \&Chairy 2010, Effect of consumer psychology to the purchasing decision back blackberry smartphone, Journal of Theoretical and Applied Management, Year 3, No. 2, pp. 128-143.

Ghozali, I 2011, Application Multivariate Analysis with IBM SPSS 19 Program, the Agency Publisher Diponegoro University, Semarang Hardius, U \&Sobari, N, 2013, Application of Multivariate Techniques for Marketing Research, Eagle Press, Jakarta.

Hawkins, Del. I., Mothersbaugh.,David.L. (2009) Customer Behavior. Building Marketing Strategy, 11 ${ }^{\text {th }}$ Mac Grow Hill International Edition., New York.

Isyanto, P, Eman, S \&Herligiani 2012, Influence Quality of Products to the Purchasing Decision blackberry mobile phones in KarawangSingaperbangsa University economics student, Journal of Management. Volume 09, p. 854-862.

Jasfar, F 2009, Management Services, Ghalia Indonesia, Indonesia. 
Kotler, P., (2005) ManajemenPemasaran, Edisi 2, penerbit PT Indeks Jakarta.

Kotler, P., Keller, K.L., (2009) Manajemen Pemasaran, Edisi 12, Jakarta: PT Index.

Kotler., Hermawan Kertajaya., Iwan Setiawan., (2010) Marketing 3.0 Erlangga: Jakarta.

Kotler, P., Amstrong. G., (2011) Principles of Marketing 13th. Edition. New Jersey: Prentice Hall

Limakrisna, N \&Susilo, WH 2012, Marketing Management, first edition, Mitra Media Discourse, Jakarta.

Mowen, C. John dan Michael Minor. (2002). Perilaku Konsumen. Alih Bahasa oleh Lina Salim. Jilid 1. Jakarta:Erlangga.

Mulyana, M \&Tandri, T 2012, Influence Perceptions of Blackberry Buying Behavior and the implications for Consumer Loyalty case studies in the School of Economics Student Unity, Ranggagading Scientific Journal, Volume 12, No. 2, pp. 157-162.

Peter, J P., Olson, JC., (2005) Consumer Behavior and Marketing Strategy, $7^{\text {th }}$ ed, Boston: McGraw-Hill//rwin.

Schiffman,L., Kanuk,L.L., (2008) Perilaku Konsumen, edisi 7 Jakarta: PT Indeks.

Sarjono, H \&Julianita, W 2011, SPSS VS LISREL, Salemba Four, Jakarta.

Sarwono, SW 2010, Introduction to General Psychology, King GrafindoPersada, Jakarta.

Sata, M \&Belete, S 2013, Determinants of Consumers Purchase Decision for Mobile Phone Devices, Journal Lecturer in Management and Accounting, Vol 01, No. 01, pp. 1-12.

Solomon, R. Michael. (2009). Customer Behaviour: A European Perspective. Financial Times, New Jersey: Prentice Hall.

Sekaran, Uma and Bogie, Roger. 2009. Research Methods for Bussiness : a skill building approach. $5^{\text {th }} \mathrm{ed}$. Wiley

Sugiyono 2012, a Business Research Method, Publisher Alfabeta, Bandung.

Supranto, J \&Limakrisna, N 2011, Consumer Behavior and Marketing Strategy, Second edition, Mitra Media Discourse, Jakarta.

Sutisna, (2003) Perilaku Konsumen Dan Komunikasi Pemasaran, Edisi ke 3, Bandung: PT Remaja Rosdakarya.

Sumarwan, U 2011, Consumer Behavior, second edition, Ghalia Indonesia, Bogor

Trenologi, Top 5, q2 smartphone market share in 2013, according idc lead samsung beat apple Retrieved on October 16, 2014 http://www.trenologi.com/2013072719635/top-5-market-share-smartphone-q2-2013.

Uddin, Reaz, Lopa, NZ, Oheduzzaman, MD, Factors Affecting Buying Decisions of Customers of mobile phone a study on Khulna City Bangladesh, International Journal of Managing Value and Supply Chains (IJMVSC), Vol.5, No. 2, pp. 21-28.

Zeithaml, V.A. 1998. Consumer's Perception of Price, Quality and Value: A Means End Model and Synthesis of Evidence. Journal of Marketing. Vol. 52, №. 3, pp. 2-22. 